\title{
Relational Becoming: Considering Classroom Dialogue in Ethico-ontological Terms
}

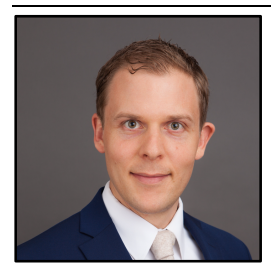

David Sabey

Equipo Academy, Las Vegas, USA

\begin{abstract}
This paper draws on Bakhtin's ethico-ontological vision of dialogue to theorize "relational becoming" on a micro-level. To do so, it introduces three "ethical dimensions of dialogue" (responsibility, responsiveness, and capacitation) and develops the interrelated concepts of addressability and presencing as analytical lenses. Drawing on transcript data from a series of high school and college students' discussions about controversial political issues, the analysis examines how interlocutors made themselves addressable, addressed each other, and were "presenced" in dialogue. It also discusses the ethico-ontological potential of these interactions, identifying a problematic tendency among interlocutors to not "show up" in verbal discourse in a variety of ways, including, in particular, reliance on abstractions.
\end{abstract}

Key words: dialogue, ethics, ontology, classroom discussions, dialogic pedagogy

David Sabey completed his doctoral studies at Vanderbilt University. As a teacher-researcher, he approaches questions about classroom discourse and education more generally in ethical terms. He currently teaches high school English, where he appreciates the opportunity to continue exploring these issues in practice.

\section{SS}

\section{Introduction}

In this paper, I approach classroom dialogue from an ethico-ontological perspective, that is, in terms of how interlocutors are involved in a social process of becoming certain kinds of people, both collectively and individually, for better or worse, in response to each other. I refer to this as "relational becoming." Relational becoming is an ontological process because it affects the nature of the world, at least insofar as it is accessible to humans. The world, from this perspective, does not exist neutrally as the pre-existent background to an interaction but is, instead, dialogically co-authored by the interlocutors. In Bakhtin's (1993) terms, it is not simply "given," but "posited" (p. 18). This is not to say that the human world is entirely emergent, created ex nihilo with each new interaction, but, to some degree, the quality of one's being in the world is at stake with every response. As Bakhtin (1984) muses, "nothing conclusive has yet taken place in the world, the ultimate word of the world and about the world has not yet been spoken, the world is open and free" (p. 166). Our existence unfolds in response to a dynamic world populated and partly authored by actual and potential interlocutors. In short, human ontology is always already dialogic.

It follows that the quality of my responses to my interlocutors and their responses to me affect our mutual being in the world-and, therefore, have a profoundly ethical import. This is why I refer to relational becoming as an ethical, in addition to an ontological, process. To be clear, I intend the word "ethical" here 
and throughout this essay to mean "having to do with ethics" or "relating to the quality of interpersonal relationships," rather than "morally good." In this sense, relational becoming can always be understood in ethical terms but is not necessarily good. Although this is a relatively straightforward observation, it has rarely been addressed head on in educational research and theory. Even educationalists working in dialogic pedagogy seem to shy away from the question of what makes a given response more or less ethically optimal (see Sabey, 2021 for a fuller treatment of this tendency, and Matusov \& Marjanovic-Shane, 2018, for a notable exception). This widespread hesitance may stem from an understandable wariness of moral absolutes, but the specter of oppressive dogma does not change the fact that our responses are ethicoontologically consequential, nor does it excuse us from the work of conceptualizing and pursuing better responses.

The primary purpose of this paper is to articulate and employ a framework for conceptualizing such "better responses." I refer to this framework as the ethical dimensions of dialogue ${ }^{1}$. For me, this framework is an attempt to take seriously both the weighty ethical obligation to respond well to one's interlocutors, and the unfinished, dialogic nature of the good. In conceptualizing and articulating the ethical dimensions of dialogue, I have been largely inspired by Bakhtin, particularly his early, explicitly ethical writing, but I do not see this framework as a direct application of Bakhtinian thought. Instead, it is my synthesis and distillation of several themes that resonate across Bakhtin's work, as will be described below. The ethical dimensions of dialogue are premised on the understanding that humans exist in the world dialogically and that all meaning-making is the byproduct of that dialogue. The great dialogue of the ages has produced important understandings, including ethical ideals such as justice. But, having emerged in the unruly reality of human relations, these ideals are shot through with the perspectives, biases, and partiality inherent in human life. Any ideal, however defined and articulated, remains an imperfect standard, incapable of adequately directing one's ethical behavior in every situation. I think, for example, of Martin Luther King Jr.'s Letter from Birmingham Jail, in which he laments the way White moderates invoked the ideal of "peace" to justify their lack of support for the civil rights movement. Although peace is certainly a worthy ideal, what it actually means in practice is not self-evident but is always a matter of perspective-and one's understanding of peace may be in tension (or even opposition) with another's, as was the case with Dr. King and the White moderates. We cannot escape the perspectival nature of meaning-making and, consequently, ethical action. With no extra-discursive and transparent ideals upon which we can always rely, we are left with the fundamental truths that we exist in response to others, each of whom has a unique perspective and voice, and that our world is the byproduct of our responses.

\section{Ethical Dimensions of Dialogue}

The ethical dimensions of dialogue are an attempt to approach dialogic ethics as a never-ending process of relating to the Other rather than having to do with some predetermined outcome. In this processual perspective, what might it mean to respond well? Put simply, I believe that, at any moment of responding, there are at least three different dynamics that have positive ethical potential ${ }^{2}$. I refer to these as 1) responsibility, which has to do with how one speaks as oneself, from one's own unique perspective, and with one's own voice, 2) responsiveness, which has to do with how one attends to and is moved by one's interlocutor(s), and 3) capacitation, which has to do with how one affords one's interlocutor(s) opportunities to respond. As I will explain, although I believe each of these ethical dimensions of dialogue has positive ethical potential, I do not believe that they are inherently good, but rather that determination of

\footnotetext{
${ }^{1}$ For the sake of simplicity, I have used the term "ethical" instead of "ethico-ontological," though I see ethics and ontology as interrelated. The ethical qualities of a given response have to do with its effect on the relational becoming of persons-in-dialogue.

${ }^{2}$ I phrase this in terms of potentiality because there is no guarantee that any of these ethical dimensions of dialogue will necessarily turn out to be good in a given interaction.
} 
their value is a matter of open or implied dialogic negotiation. In what follows, I will describe these ethical dimensions of dialogue and briefly discuss how I see them in relation to Bakhtinian concepts.

\section{Responsibility}

The ethical dimension of responsibility, which has to do with speaking as oneself, from one's own unique perspective, and with one's own voice, derives from the ontological fact that each person is unique. Bakhtin (1993) writes, "I occupy a place in once-occurrent Being that is unique and never-repeatable," adding that this uniqueness is "compellently obligatory" (p. 40). The spatial language Bakhtin uses here affords an ocular metaphor (see Bakhtin 1993, p. 62-63): From my particular vantage point, I see the world in a way that no one else does. In a sense, I am the only eyewitness of some aspect of reality, and this fact obligates me to be a witness, to share what only I have seen. Bakhtin (1993) refers to this obligation as a "non-alibi in Being" (p. 40). Because I occupy a unique place in existence, I can never claim that someone else was in my place or that I was elsewhere. I never have an alibi and, therefore, must act responsibly.

Expounding on this idea, Bakhtin compares a responsible way of being to signing one's name to a document, writing that life lived without this sense of obligative uniqueness is like "an unsigned document...[or] a rough draft." He goes on to say that "only through the answerable participation effected by a unique act or deed can one get out of the realm of endless draft versions and rewrite one's life once and for all in the form of a fair copy" (p. 44). I take "a unique act or deed" to mean that the act is one's own, performed without an alibi, from one's particular place in existence. "Answerable participation," then, is taking part in life in this way-as oneself, with skin in the game, with one's name on the line, being willing to take responsibility for what one does and what one is uniquely capable of doing. It is to respond to the concrete particularity of each moment as oneself, uniquely positioned and obligated by that uniqueness. This is no easy task. Indeed, writing at the end of his life, Bakhtin (1986) returned to these ideas, saying, "The $I$ hides in the other and in others, it wants to be only an other for others, to enter completely into the world of others as an other, and to cast from itself the burden of being the only I (I-for-myself) in the world" (p. 147), echoing his earlier recognition that people are not always disposed to shoulder the burden inherent in their uniqueness: "I can try to prove my alibi in Being, I can pretend to be someone I am not. I can abdicate from my obligative (ought-to-be) uniqueness (Bakhtin, 1993, p. 42).

As Bakhtin implies, responsibility entails risk: There is some risk in signing one's name, taking responsibility for one's words and choices, and relinquishing the chance to claim an alibi. Sensing some possible embarrassment, discomfort, or liability, one might understandably protect oneself by avoiding accountability, but doing so may withhold from one's interlocutors a potentially beneficial perspective. Indeed, the potential benefit one's perspective may provide an interlocutor is the reason why responsibility, in the sense I am using it here, is one of the ethical dimensions of dialogue. This benefit derives from what Bakhtin (1990) calls the "excess of my seeing in relation to another human being" (p. 24). Given that each individual is uniquely situated in existence, no one's field of vision ever entirely overlaps with another's; each can see what others cannot. In Bakhtin's view, this simultaneous surplus and lack bind self and Other together in a state of interdependency and complementarity. In this light, Bakhtin's (1986) discussion of how great literary works "outgrow what they were in the epoch of their creation" (p. 4) can be seen as parallel to what happens to the Other when one shares aspects of one's excess of seeing. Referring to the way Shakespeare's plays continue to generate new insights, Bakhtin explains, "The author is a captive of his epoch, of his own present. Subsequent times liberate him from that captivity" (p. 5). Analogously, each individual is a captive of their own place in existence and can be "liberated" by someone who stands elsewhere, with an excess of seeing relative to them. Seeing things that others cannot, my unique perspective may help my interlocutors beyond their current field of vision. 


\section{Relational Becoming: Considering Classroom Dialogue in Ethico-ontological Terms}

David Sabey

\section{Responsiveness}

I characterize responsiveness as a dynamic openness and careful attention toward the Other which entails an ongoing cycle of attuning to the particularities of one's interlocutor(s) and adjusting accordingly. Responsiveness can be understood as the flipside of responsibility because it involves viewing the Other as a unique and answerable self for whom oneself is an Other who stands to benefit from their unique perspective. Without this recognition-without tempering responsibility with responsiveness-there is an ethical danger in simply speaking from one's own place in the world. This is because one's excess of seeing can fuel the assumption that the Other is entirely transparent, knowable, and judgable - "finalizable" is Bakhtin's (1984) term (p. 61). Thus, rather than finalizing the Other, one must seek to "consummate" them (Bakhtin, 1990, p. 14), offering a unique outside perspective that supplements their current understanding, but respecting their "holy of holies" (Bakhtin, 1984, p. 59), their potential to transcend categorization, resist definition, and respond differently than expected. Meditating on this in relation to Dostoevsky's polyphonic novel, which he seems to view as a model of ethically optimal self-Other relationships ${ }^{3}$, Bakhtin (1984) writes,

[T] he author's consciousness does not transform others' consciousnesses...into objects, and does not give them secondhand and finalizing definitions. Alongside and in front of itself it senses others' equally valid consciousnesses, just as infinite and open-ended as itself. It reflects and re-creates not a world of objects, but precisely these other consciousnesses with their worlds, re-creates them in their authentic unfinalizability (which is, after all, their essence) (p. 68).

This is the key-to speak as a unique self while simultaneously responding to one's interlocutors with the recognition that they are just as unique and open-ended.

Bakhtin (1993) notes that one way to "finalize," rather than "consummate," one's interlocutors is "to see in every other, in every object of a given act or deed, not a concrete uniqueness which participates in Being personally, but a representative of a certain large whole" (p. 53). Recognizing that "Man-in-general does not exist; I exist and a particular concrete other exists" (Bakhtin, 1993, p. 47), one must seek to understand and relate to one's interlocutors in their particularity, not simply because they are unique, but because they are always in the process of becoming something else. In the Author and Hero essay and later in the Dostoevsky book, Bakhtin discusses this in terms of (non)coincidence: As everyone occupies a unique location in Being, nobody "coincides" with anybody else (1990, p. 13), and as each person is also always in a state of becoming, nor do they ever entirely coincide with themselves (1984, p. 59). In carefully attending to the Other, one must never lose sight of their radical alterity and unfinalizability.

Recall that responsiveness entails both a careful attention and dynamic openness toward the Other. I appreciate the adjective "careful" as a modifier of the noun "attention" because of the way it implies thoroughness, but also suggests a certain benevolence. Indeed, Bakhtin (1990) goes so far as to suggest, "What I must be for the other, God is for me. What the other surmounts and repudiates within himself as an unworthy given, I accept in him and that with loving mercy as the other's cherished flesh" (p. 56). Bakhtin who was by all accounts a faithful, if somewhat unorthodox, believer sees in Christ a divine example of what he calls vzhivanie or "live entering" (sometimes translated as "living into" or "active empathy"), in which the self (Christ) addresses the Other from a position of both outsidedness and love-the kind of love that

\footnotetext{
${ }^{3}$ There is some debate about how analogous Dostoevsky's authoring of novels is to the way interlocutors "author" each other-or if authorship is an appropriate metaphor for describing interpersonal relationships. Although I think it is obvious that there are significant differences between the relationships of authors and their characters and those of living interlocutors, I am comfortable with the idea that our responses to each other shape and constrain our being in the world and are, therefore, a kind of authoring with some analogy to other forms of authorship, including Dostoevsky's novel-writing.
} 


\section{Relational Becoming: Considering Classroom Dialogue in Ethico-ontological Terms}

allows one "to make serious extended incursions into the depths of the other, to take seriously its unfinishedness" (Emerson, 2000, p. 18), to deeply understand but never to determine, to live alongside but never to merge.

In addition to carefully attending to one's interlocutors, one must also open oneself to them. A part of this involves being open to the possibility that one has not entirely understood the Other, that there is more to understand; one might even deliberately approach the encounter, expecting to be surprised (Matusov et al., 2016). Another kind of openness has to do with willingness to adjust in response to the Other, to change as a result of one's encounter with the Other. This is what Warnick, Yacek, \& Robinson (2018) refer to as the "responsibility to be moved" (p. 36). Referring to understanding a work of art, but with ethical implications, Bakhtin (1986) writes, "The person who understands must not reject the possibility of changing or even abandoning his already prepared viewpoints and positions. In the act of understanding, a struggle occurs that results in mutual change and enrichment" (p. 142). In order for a self/Other relationship to be mutually enriching, the self must be willing to be responsively moved.

\section{Capacitation}

The third ethical dimension of dialogue has to do with how one's responses to the Other enable them to respond in certain ways, bridging the gap between self and Other in their ongoing interrelations. In a sense, this is an aspect of "live entering," in which, after empathizing with the Other and returning to one's own place in Being, one replies to the Other in a way that combines the perspectives of outsideness and empathy, offering to the Other a unique and potentially enriching perspective. Morson \& Emerson (1990) describe the process thus: "Without trying to finalize the other or define him once and for all, one uses one's 'outsideness' and experience to ask the right sort of questions. Recognizing the other's capacity for change, one provokes or invites him to reveal and outgrow himself' (p. 242).

In Bakhtin's (1984) account, Dostoevsky developed a method to author his characters in a way that renders them capable of responding. He explains that "the author's discourse about a character is organized as discourse about someone actually present, someone who hears him (the author) and is capable of answering him" (p. 63). Indeed, one of the things that makes Dostoevsky's writing so remarkable to Bakhtin is that the characters do not seem predetermined and entirely subject to the author's vision; rather, Dostoevsky enables his characters to respond to him, something that is evident in his creative process:

\footnotetext{
Dostoevsky did not first work out a structure, plan, or overall plot of the work. Rather, he first imagined specific 'voices,' that is, integral personalities with their own ideas and sense of the world...Dostoevsky then...contrived situations that could provoke these people into dialogue with each other and with his own views. Characters join in dialogue, Dostoevsky himself may in some form participate, and the characters (perhaps also the author) outgrow themselves in the process. Sometimes Dostoevsky continues the dialogue in new scenes; at other times, he leaves preliminary dialogues in his notebooks and starts anew with characters recently made more complex (Morson \& Emerson, 1990, p. 245).
}

Although most interactions between people look very different from Dostoevsky's drafting, there are ethical principles that are applicable across these situations. Like Dostoevsky, one ought to view (and author) one's interlocutors without predetermined notions of who they are and what they will do, and must provide space and develop processes through which to enable the Other to respond movingly, in ways that will enrich both self and Other, rendering them capable of ongoing and potentially enriching interactions. 


\section{Clarification}

Before continuing, let me clarify a few items: First, while I think it is useful to describe these ethical dimensions of dialogue separately, in practice, they are very much interrelated. Still, even though they are interrelated, each dimension can help us attune in different ways to our interactions. Second, I am not suggesting that speaking responsibly, responsively, and/or capacitatingly is necessary good at every moment. Although each of these ethical dimensions of dialogue has potential to be generative and enriching, each interaction is unique and calls for particular responses that cannot be predetermined. The challenge for the ethically minded interlocutor is to discern in the particularities of the moment how best to respond. The ethical dimensions of dialogue are not an alibi; they are not the criteria of an ethically optimal response. Instead, I see them as sensitizing concepts that can help us attune to the ethical potential of certain kinds of responses and, over time, become more discerning of how best to respond at any given moment.

\section{Addressability and Presencing as Analytical Lenses}

Any moment of dialogue is ethico-ontologically significant, and the ethical dimensions of dialogue help us attune to the relational becoming of interlocutors. In other words, they help us notice patterns in how interlocutors respond to each other (and, consequently, become certain kinds of people in relation to each other), and to imagine alternatives. This is what I attempt to do in the following analysis. For the purposes of this paper, I consider the relational becoming of interlocutors at a micro-level, regarding interactions that lasted between several seconds and several minutes. I do so with the assumption that these small-scale moments of relational becoming are consequential (see, for example, Wortham's (2008) discussion of how durable identities emerge across multiple interactions, as interlocutors address and respond to each other in similar ways over time).

One way to examine the relational becoming of persons-in-dialogue is by attending to their addressability. Whenever we speak, we make certain aspects of our thinking, personality, identity, and/or history salient and available to others for address; we make ourselves addressable in certain ways. Interlocutors' relational becoming is a function of how they render themselves addressable and how they address (or not) that which each other makes addressable. Both prior to and in the process of making oneself addressable and/or by being addressed in certain ways, interlocutors become present to each other in certain ways, or, at least, they potentialize that presence, becoming presence-able in certain ways. From this perspective, one's presence is not a given, but is dynamically authored in dialogue with one's interlocutors. In other words, we are not simply present, but are "presenced" to each other as we are rendered addressable in certain ways. This is not only the result of actual interactions, but is shaped by our sense of the genre of activity we are engaged in. A discussion, for example, affords certain kinds of presencing, predisposing interlocutors to co-author each other in certain ways.

For example, if I were to find myself in a classroom teaching situation, I would likely make myself addressable as a teacher either explicitly or implicitly ("Can I get your attention? We're about to start class.") and address my interlocutors as students ("What did you think about last night's reading, Bryan?"). If Bryan were to say, "What reading?" I might consider him to be addressable as a disorganized student or a class clown, especially if we had had similar interactions in the past, and I would likely address him accordingly. If Bryan were to explain that he had played in a championship soccer game last night and had not had time to complete the reading, he would make himself addressable as, among other things, an athlete. Perhaps another student would address Bryan as such, saying, "Yeah, tough luck, Bryan. But you guys played hard. It was a good game." This would make Bryan addressable as having lost and, likely, as being disappointed, and the speaker as someone who had watched the game. The way in which we navigated these moments of addressability would affect the way various members of the classroom community were presenced to 
each other, and largely determine our relational becoming over the course of the class. If we repeatedly had similar interactions, these kinds of addressability would likely become more durable over time.

For the purpose of this paper, I will define addressability as the ways in which interlocutors are rendered addressable to each other, and presencing as the dialogic process of becoming present to one's interlocutors in a certain way. Both dynamics are subjective-how my interlocutors consider me to be addressable and how they perceive my presence are a matter of perspective that may not be entirely shared-though aspects of addressability are evident in discourse. While presencing is harder to empirically examine, I appreciate the way it attunes us to the ethico-ontological dynamics of dialogue: Any interaction is constituted by interlocutors who are becoming certain persons-in-dialogue; they are not simply present for the discussion but are being presenced in the discussion. The stakes are not simply interlocutors' conceptual understandings, but their being in the world.

In the following examples, I will draw on these lenses to analyze the relational becoming of certain groups of students involved in a series of discussions; that is, how, at a micro level, students were made addressable, subsequently addressed, and presenced in the process of discussing. To be clear, while many aspects of addressability are evident in verbal discourse, it is impossible to empirically verify every way in which interlocutors understand each other to be addressable. Relatedly, how someone is presenced in a certain situation is perspectival and subjective. We are always presenced and rendered addressable to someone, and different interlocutors may have varying senses of our presence/addressability. In the subsequent examples, my analysis will rely on my own retrospective perspective. In many cases, I believe this perception was shared by others, but it is entirely possible that this is not the case. Additional analyses that considered how multiple interlocutors understood each other's addressability/presence would be illuminating but are beyond the scope of this paper.

\section{Research Context}

The examples below come from a study in which, as a teacher-researcher, I facilitated a series of discussions and meta-communicative activities with three different groups of students, the first, a group of undergraduates (mostly freshmen, around 18 years old), and the second and third composed of 9th graders (around 14 years old). My purpose in each of these groups was to explore how I might pedagogically cultivate ethically optimal dialogue in the context of classroom discussions about controversial political issues. All students who participated in the discussions were aware of my intent, though they had different understandings of what that means and varying degrees of investment in that goal. The group of undergraduates had enrolled in a one-credit elective course I taught about talking across political differences, and the high school students voluntarily participated in the discussions with me during their "personalized learning time," a daily ungraded study hall period supervised and occasionally directed by a teacher. In both cases, the academic stakes were relatively low.

The topics we discussed were proposed by group members and selected through a vote, but it would be inaccurate to claim that the groups were entirely democratic. I was admittedly an authority figure, directing the groups and facilitating the discussions. My approach to facilitation changed over time both within and between groups, as my understanding of ethically optimal dialogue and the needs of my studentinterlocutors evolved. At times, I facilitated the discussions with a light hand, letting the discussion flow organically, sometimes even explicitly removing myself from the conversation, while at other times, I took a more heavy-handed approach, intervening to preempt or repair what seemed to me to be problematic interactions or asking students to practice certain discursive moves.

The students in the three groups represented a variety of backgrounds, as summarized in the following charts. The undergraduate students attended a prestigious private university, and the 9th graders 
attended a diverse urban public high school. Some of the differences in their social background and academic achievement are evident in their verbal discourse. Although I will provide some additional commentary about these students in my subsequent analysis, for the purpose of this paper, I simply want to posit that the participants in the study are relatively diverse on a variety of dimensions and, thus, that the interactions I will be analyzing are not unique to any particular demographic-that the lenses of addressability and presencing are broadly applicable and that the tendencies I document are likely to manifest in a variety of contexts, especially in school.

\begin{tabular}{|l|l|l|}
\hline \multicolumn{3}{|l|}{ GROUP 1 (Undergraduates) } \\
\hline David* & White & M \\
\hline Keith* & White & M \\
\hline Liam & White (Germany) & M \\
\hline Makenzie & Black & F \\
\hline Anand & Asian American (India) & M \\
\hline Brodie & White & M \\
\hline Ted & White & M \\
\hline Jane & White & F \\
\hline Savannah & White & F \\
\hline Joe** & Black & M \\
\hline
\end{tabular}

*Instructors/facilitators

**Joe was Makenzie's brother, a college senior, who was invited to the final discussion of the group.

\begin{tabular}{|l|l|l|}
\hline \multicolumn{3}{|c|}{ GROUP 2 (9th Grade) } \\
\hline David* & White & M \\
\hline Jabari & Black & M \\
\hline Ivan & White (Ukraine) & M \\
\hline Sandy & White & $\mathrm{F}$ \\
\hline Jimena & Latinx & $\mathrm{F}$ \\
\hline Amala & Asian American (Vietnam) & $\mathrm{F}$ \\
\hline Jared & Latinx & $\mathrm{M}$ \\
\hline Yvette & Black (Kenya) & $\mathrm{F}$ \\
\hline Rosa & Latinx & $\mathrm{F}$ \\
\hline
\end{tabular}

\begin{tabular}{|l|l|l|}
\hline \multicolumn{3}{|c|}{ GROUP 3 (9th Grade) } \\
\hline David* & White & $\mathrm{M}$ \\
\hline Patience** & Black & $\mathrm{F}$ \\
\hline Brandin** & Black & $\mathrm{M}$ \\
\hline Luis & Latinx & $\mathrm{M}$ \\
\hline Noemi & Latinx & $\mathrm{F}$ \\
\hline Derya & Kurdish & $\mathrm{F}$ \\
\hline Cody & White & $\mathrm{M}$ \\
\hline Laura & Latinx & $\mathrm{F}$ \\
\hline Adriana & Latinx & $\mathrm{F}$ \\
\hline Aliyah & Black (Sudan) & $\mathrm{F}$ \\
\hline Graciella & Latinx & $\mathrm{F}$ \\
\hline
\end{tabular}

*Facilitator

**Patience and Brandin were step-siblings. 
Most of the discussion below is the result of my retrospective analysis in which I examined the transcripts from our meetings and sought to understand them in terms of ethically optimal dialogue. With my interest in the ethical dimensions of dialogue, I was initially drawn to moments in which students seemed to "show up" in their comments or, conversely, when they seemed to be "hiding" in some way as being related to responsibility. Consider, for example, the difference between saying, "I disagree" and "Some people might disagree." In the former, the speaker "shows up" more clearly than in the latter. This is not to say that simply using "I-statements" is necessarily responsible, nor that it is irresponsible to not make oneself explicitly present in a comment, but the way interlocutors make themselves addressable certainly affects their relational becoming. Attending to how my student interlocutors made themselves addressable led me to notice how others addressed them, which I have come to see as one aspect of responsiveness. Again, I do not necessarily think that it is always ethically obligatory to address one's interlocutors in every way they make themselves addressable, but the way in which we address our interlocutors does affect the kind of person they become within the context of the interaction.

As I examined these moments, I came to see them in terms of addressability and presencing. Furthermore, I came to see that the way interlocutors were made addressable and presenced in the group was a joint accomplishment-not the result of any individual's comments. The way interlocutors make themselves addressable, which affects how they are presenced in the group, is itself a response and, thus, a joint accomplishment of the group. In other words, I came to see that the whole group was responsible to some degree for the ethical quality of the discussion.

\section{Data Analysis}

In what follows, I analyze six different episodes of varying lengths from all three groups. I hope that applying the lenses of addressability and presencing to this variety of examples will both show their usefulness and help readers attune to some of the ethico-ontological dynamics of the interactions in light of the ethical dimensions of dialogue. As readers will see, my analytical methods are very much akin to traditional discourse analysis of interlocutors' positioning, though I find the notions of addressability and presencing, which emerged in my initial study of the transcripts, to be a productive lenses for this kind of analysis. However, I am not merely interested in documenting discursive patterns in these groups' discussions, but in considering their ethico-ontological qualities and potential. Thus, in light of the ethical dimensions of dialogue, I hope that my analysis of addressability and presencing will raise questions about how we could have responded differently and how we ought to respond in the future. This aspiration exceeds the scope of traditional empirical analysis, as it has to do not only with discernable historical reality but with subjective values and potentiality. This approach may be aligned with what Matusov et al. (2019) call "dialogic analysis." In that vein, after analyzing each of the episodes and providing some commentary, I imagine how some of the episodes could have gone differently. The purpose of this reimagining is to raise questions about which kinds of responses might lead to different and perhaps more generative and enriching forms of relational becoming. I do not pretend to have final answers, but I think asking these questions is vitally important and I hope the conceptual and analytical tools I develop in this paper will help us ask good questions and, perhaps, arrive at some preliminary responses.

\section{Episode \#1: Sidestepping a Certain Address (Group 3)}

This first example comes from Group 3's discussion on racism. The speakers in the following transcript are me (David) and Noemi, who in our discussion group was always rather reserved. She selfidentified as shy and that is, indeed, how I came to see her and respond to her (i.e., that is how she was presenced to me), as we will see below. In the course of this discussion, several students, including Noemi, indicated that their parents had immigrated to the United States, and, in response, I had invited them to 
share their stories with the group, if they would like. After each of the other students did so, the following exchange took place:

\begin{tabular}{|l|l|l|}
\hline David & Noemi, do you want to share? & 1 \\
\hline Noemi & $\begin{array}{l}\text { It's a long story but like, I don't know like the full story because like usually I never like, } \\
\text { listen to my, [David: Mm-hmm] my mom say it, [David: Mm-hmm] } \\
\text { but like when she tells my other siblings. }\end{array}$ & 2 \\
\hline David & Do you want to share anything you do know or? You don't have to. & 4 \\
\hline Noemi & I, I don't know the full story, so. & 5 \\
\hline David & Okay. & 6 \\
\hline
\end{tabular}

I begin by addressing Noemi as possibly wanting to share her family's story (line 1). In her response, she sidesteps this address and instead makes herself addressable as not knowing the full story (line 2), as generally not listening to her mother's storytelling (lines 2-3), and as having siblings who do listen (line 4). Although I conceivably could have responded by addressing her in any of these ways, I mostly repeat my initial address, asking once again if she wants to share the part(s) of the story she knows, and reiterate that she does not have to do so (line 5). Again, she sidesteps this address and makes herself addressable as not knowing the full story (line 6), which I interpret and accept as a bid to be excused from comment (line 7). Notice how Noemi's presencing is dialogically co-authored, particularly in how I address her in ways that do not align with the ways she makes herself addressable. This is not to say that, had I addressed her otherwise, she necessarily would have responded differently, but a different address may have opened up other possibilities of relational becoming. As it was, this interaction simply presenced Noemi as a shy student who did not really want to participate in the discussion.

\section{Episode \#2: Obscuring Addressability (Group 1)}

The following exchange took place during a discussion about abortion among the undergraduate group. Brodie, the primary speaker in the exchange, was the most outspoken liberal in the group and often the person who spoke the most in our discussions, both because he had strong opinions and because he tended to be rather verbose in articulating them. He was aware of this tendency and attributed it to his upbringing in a conservative state where he often found himself in situations in which he was the only liberal and had to defend progressive politics single-handedly. What is particularly interesting to me is how different Brodie's participation in our discussions was from Noemi's, but how, when viewed in terms of addressability, both seem to be "hiding" in some ways.

The extended transcript included below begins as Brodie responds to a brief discussion among other students about the comparability of a human fetus to a non-human animal, indicating that he largely agreed that a fetus need not be considered human.

\begin{tabular}{|l|l|l|}
\hline Brodie & I do kind of- I'm interested by this notion that the humanistic quality of life, & 1 \\
& like often people disassociate humans as like a species, or like an animalistic & 2 \\
& species, but like the humanistic quality of life, I don't- I would agree. I don't & 3 \\
think it's found as a fetus. I think there is something about a shared human & 4 \\
& experience that gives you a sense of humanistic life, and I- I don't know if I & 5 \\
would've went so far to like name examples, but I agree with the theory, I & 6 \\
& guess. I guess, um something else that I've heard raised a lot recently, people & 7 \\
& often when they talk about abortions will say that they're worried the baby or & 8 \\
fetus will suffer. A baby will suffer if born. Something else that I've heard & 9 \\
\hline
\end{tabular}




\begin{tabular}{|c|c|c|}
\hline & $\begin{array}{l}\text { raised recently is people having a very philosophical and ethical debate is, what } \\
\text { world am I bringing a child into? Not that the child might necessarily suffer } \\
\text { when it gets here from like anything physical or biologically wrong with it, but } \\
\text { um, this id- this notion that maybe you're bringing into a child, a child into a } \\
\text { world that is not fit for it to be prosperous or live a healthy, good life, whatever } \\
\text { standards you want to set to it. This notion that just because a child is born, } \\
\text { does not, or a baby is born, it is not instantaneously guaranteed the same equal } \\
\text { human experience that every other baby is. So maybe there has to be this } \\
\text { ethical question of what life am I bringing a person into? And I think that's just } \\
\text { something that, it's been very recently talked about. But I don't think that most } \\
\text { people are acknowledging like there are different qualities of life that may } \\
\text { impact this decision. }\end{array}$ & $\begin{array}{l}10 \\
11 \\
12 \\
13 \\
14 \\
15 \\
16 \\
17 \\
18 \\
19\end{array}$ \\
\hline Liam & Would you- would you sign your name to that? (Laughter from group) & 20 \\
\hline Brodie & $\begin{array}{l}\text { I personally believe, yeah. At some point you have to consider it's inethical for } \\
\text { you to think, I can have a child, we'll figure it out after it happens. Like we'll } \\
\text { figure out if this was a life that this child deserved or if this is the life that any } \\
\text { human deserved, like I don't think, I feel like that's very inethical as a parent, } \\
\text { which would be like, oh, okay, well let me accidentally get pregnant, whatever } \\
\text { the situation may be, and then have a child. I feel like that's an inethical } \\
\text { situation to bring them into like a very, if there are situations that it's not fit for } \\
\text { a person to live in, including yourself. If you feel like you're in a situation that's } \\
\text { unfit for you, to bring another person into that situation seems very inethical } \\
\text { and irresponsible. }\end{array}$ & $\begin{array}{l}21 \\
22 \\
23 \\
24 \\
25 \\
26 \\
27 \\
28 \\
29\end{array}$ \\
\hline Liam & Right. & 30 \\
\hline Ted & You gotta ( ) & 31 \\
\hline Anand & Can I ask a question? & 32 \\
\hline Brodie & Please & 33 \\
\hline Anand & $\begin{array}{l}\text { So, what you were saying- So, um, so like how would you view it if, let's say, } \\
\text { someone who's born in a rich family and had a teen pregnancy and they were at } \\
\text { high school, or whatever, and they decided to get an abortion. Compared to } \\
\text { someone who was like, in a actually a very difficult situation, where they could } \\
\text { not raise the baby in a healthy environment. Would you see- would it- would } \\
\text { one be more okay than the other? }\end{array}$ & $\begin{array}{l}34 \\
35 \\
36 \\
37 \\
38\end{array}$ \\
\hline Brodie & I'm very pro choice, I think either's fine. & 39 \\
\hline Anand & So okay, so- & 40 \\
\hline Brodie & $\begin{array}{l}\text { but I, but I think that is something that a lot of, um, a lot of people } \\
\text { and, very, including myself, there's a actually a film that raises this notion to } \\
\text { me, it was called, it was called A Private Life. It's about a couple that's trying to } \\
\text { have a baby and they have to do it, not like naturally, I do not, it's like a sperm } \\
\text { don-, they get a sperm donor. But um, while she's like filling out the papers, }\end{array}$ & $\begin{array}{l}41 \\
42 \\
43 \\
44 \\
45\end{array}$ \\
\hline
\end{tabular}




\begin{tabular}{|c|c|c|}
\hline & $\begin{array}{l}\text { she goes to this kind of like a meta-level philosophical like struggle with like, } \\
\text { What am I doing to this child? Like they're coming into a world that is not in a } \\
\text { good place right now. And then she goes off on this tangent about all the issues } \\
\text { in the world that she's bringing a child into. And until I saw that, I was like, } \\
\text { wow, I never thought of it like that. I always thought of it much like you all are } \\
\text { thinking, or most people think about it as like, Am I bringing a child into a } \\
\text { place where they are going to suffer physically or for whatever biological } \\
\text { reason, where it's like, at some point there's like a moral question of like suffering too. }\end{array}$ & $\begin{array}{l}46 \\
47 \\
48 \\
49 \\
50 \\
51 \\
52\end{array}$ \\
\hline David & $\begin{array}{l}\text { So when you talk about the world, you're not talking about the- like the family's } \\
\text { socioeconomic status. }\end{array}$ & $\begin{array}{l}53 \\
54\end{array}$ \\
\hline Brodie & $\begin{array}{l}\text { I think- I think you can go to both. I think there are situations where it's just the } \\
\text { socioeconomic status and other situations you look at- in the tangent, she's like, } \\
\text { what am I bringing it out into? And then she goes off, she's like climate change } \\
\text { and war and famine and disease and all the, and she just goes off on a tangent } \\
\text { about everything that's wrong with the world, and while I didn't necessarily } \\
\text { agree with all of that, I still found it interesting that like this is something that is } \\
\text { interesting to think about, and like a lot of countries are sharing like a very } \\
\text { similar like philosophy of like how like aside kind of but like they're saying } \\
\text { some similar philosophy, like they want a negative population growth because } \\
\text { they're so overpopulated and that terrifies them as like a government, that } \\
\text { they're encouraging, like very heavily, like negative population growth. Like a } \\
\text { lot of western European countries, and like China is like very crazy about how } \\
\text { spec- like, like crazy's the wrong word, but very, very restrictive on their } \\
\text { population growth. But like it is something that like, is not like an } \\
\text { Americanized concept yet, which I just find interesting. }\end{array}$ & $\begin{array}{l}55 \\
56 \\
57 \\
58 \\
59 \\
60 \\
61 \\
62 \\
63 \\
64 \\
65 \\
66 \\
67 \\
68\end{array}$ \\
\hline Liam & $\begin{array}{l}\text { Um, so there, so it's either the, so there are two two like kind of points here as I } \\
\text { see it. It's one of them is the um, like the world we live in due to like stuff like } \\
\text { climate change and stuff is becoming so horrible that potentially every child } \\
\text { might not like have a good life. And the other one is depending on your } \\
\text { situation, your child might- depending on your socioeconomic or whatever } \\
\text { situation, that your child might not have a good life. Those- so those are the } \\
\text { two possible like arguments. }\end{array}$ & $\begin{array}{l}69 \\
70 \\
71 \\
72 \\
73 \\
74\end{array}$ \\
\hline Brodie & $\begin{array}{l}\text { I don't know if it's limited to just those two. I just, I thought that question that } \\
\text { was raised was very interesting and I was just, it, what I won't sign my name to } \\
\text { is that I agree that that's a probable cause for an abortion. I'm very pro-choice } \\
\text { for the first two trimesters. I don't feel like you need a reason that you don't } \\
\text { want to have a child don't have a child. Uh third trimester, I think it has to come } \\
\text { down to viability or if it's going to harm or kill the mother. But I don't know if } \\
\text { I'm uh willing to sign my name to, oh I wouldn't have a child right now because } \\
\text { of climate change, but I do mean that it's something that people have to start } \\
\text { asking, is like, what is, what is the environment they're coming into? }\end{array}$ & $\begin{array}{l}75 \\
76 \\
77 \\
78 \\
79 \\
80 \\
81 \\
82\end{array}$ \\
\hline Liam & $\begin{array}{l}\text { So you're, you're just stating this argument, but you don't necessarily even } \\
\text { believe in its validity. }\end{array}$ & $\begin{array}{l}83 \\
84\end{array}$ \\
\hline
\end{tabular}




\begin{tabular}{|l|l|l|}
\hline Brodie & $\begin{array}{l}\text { I don't agree with every facet of the argument. I agree with raising the } \\
\text { questions. }\end{array}$ & 85 \\
\hline David & $\begin{array}{l}\text { You would say, it could be the ethical choice to choose to abort a baby given } \\
\text { world conditions. [Brodie: Yeah] That that is a defensible argument. }\end{array}$ & 86 \\
\hline Brodie & $\begin{array}{l}\text { I think- Yeah. I think it's defensible and it- and to say, but yeah, I can't, I don't } \\
\text { agree with every facet, but I would, I wouldn't judge someone who made that } \\
\text { argument and that was their defense for having an abortion. }\end{array}$ & 87 \\
\hline Liam & You wouldn't judge anybody for having an abortion. & 89 \\
\hline Brodie & $\begin{array}{l}\text { Uh, if a mother was, we used, what was it, } 40 \text { weeks if it was 39th week and } \\
\text { that the fetus was in every scientifically provable way viable outside of the } \\
\text { womb, had an abortion. I don't know if I could see a moral reason for that. }\end{array}$ & 91 \\
\hline Liam & Okay, gotcha. & 92 \\
\hline
\end{tabular}

After responding to an idea brought up by his classmates, Brodie maintains the floor and pivots to "something else that l've heard raised a lot recently" (lines 6-7). He goes on to introduce two different ways people talk about abortion, one having to do with suffering (lines 7-8), the other having to do with quality of life (lines 8-13). Though the distinction between the two orientations is not entirely clear, he seems to align with the latter perspective, but does so obliquely. In Goffman's (1974) terms, he acts as the "animator" of other speakers rather than revealing himself as the "principal" and/or "author" of these ideas, a documented means of achieving discursive neutrality (Clayman, 1992). Although this is likely more habitual than deliberate, he does a lot of discursive work to obscure where exactly he stands relative to the ideas he introduces. In this initial turn, the closest he gets to self-revelation, to making himself addressable as having a particular opinion, is when he says, "So maybe there has to be this ethical question of what life am I bringing a person into?" (line 16). Immediately afterwards, however, he creates some distance between himself and that question, saying, "And I think that's just something that, it's been very recently talked about" (lines 17). With this comment, he makes himself addressable as someone who has heard this idea but not necessarily as the bearer of that opinion-as a hearer, not a believer. If his opinion is that the quality of life a newborn would inherit is a legitimate criterion when considering abortion, he discursively inserts other people between himself and that idea, saying "I don't think that most people are acknowledging like there are different qualities of life that may impact this decision" (lines 17-19). In terms of what Brodie makes explicit, he becomes addressable only as someone who has heard other people talking about abortion and who has some "meta" understanding of how they are (not) discussing it.

In the moment, my sense was simply that Brodie was verbose, but I have come to see this tendency as also functioning as a kind of self-protection. Perhaps Brodie participates in the discussion in this selfprotective way simply because he is exploring these ideas, or perhaps because he is wary of the consequences of taking a hard and potentially controversial stand. In response, Liam calls Brodie out, asking, "would you sign your name to that?" (line 20), a remark that invokes a Bakhtinian concept (i.e., "name signing") we introduced to the class and seems intended to prod Brodie to put himself on the line, to make himself directly addressable in relation to these ideas. The laughter this question elicits may suggest that other students also sense how Brodie's comments obscure his addressability. In lines 21-29, Brodie responds, speaking more directly as himself and explaining that he considers it unethical to bring a child 


\section{Relational Becoming: Considering Classroom Dialogue in Ethico-ontological Terms}

into a situation that is unfit for human life, leaving open, however, the question of what qualities make a given situation more or less "fit."

Anand picks this up and asks if Brodie sees two different scenarios differently-if abortion would be "more okay" in one (line 38)—implicitly searching for the criteria Brodie has in mind. Brodie responds by identifying as "pro-choice" and saying that "either's fine" (line 39). Anand seems poised to further examine Brodie's stance when Brodie continues. Echoing some of his earlier animation of other voices, he begins by referring to "something that...a lot of people" (line 41) presumably are saying; he adds himself to the group ("including myself" line 34) but then, rather than directly sharing what he thinks, defers to the film $A$ Private Life, giving voice to its protagonist as she considers using a sperm donor to become pregnant. At line 42, the comment becomes autobiographical, as Brodie narrates how the movie changed his perspective. He explains, "I always thought of it much like you all are thinking, or as most people think about it" (lines 49-50). I take the revision from "you all" to "most people" to indicate a recognition that it might not be appropriate to label the entire group as having a certain opinion; in either case, however, Brodie seems to address a seemingly homogenous group of people and not any person(s) in particular. Apparently, in Brodie's mind, the perspective held by most people, including his most proximate interlocutors, has to do with physical suffering or biological concerns, whereas his new perspective concerns the "moral question of...suffering" (line 52).

Still seeking clarity, I ask another follow up question. As he begins answering, he seems to approach his own opinion, saying, "I think there are situations where it's just the socioeconomic status and other situations you look at" (lines 55-56), when he breaks off and once again begins to give voice to the film's protagonist (lines 56-59). Done referencing the movie, Brodie initially hedges, saying, "I didn't necessarily agree with all of that" (line 59) and then takes an ambiguous stance: "this is something that is interesting to think about" (line 60). After referring to "a lot of countries" who have a similar philosophy (lines 60-67), he concludes, saying, "which I just find interesting" (lines 67-68). Brodie's repeated ventriloquations and ambiguous stances make it hard to identify where exactly he stands in all this; he makes himself addressable to the group as someone with interest in and familiarity with ethical questions about abortion, extant conversations, and certain national policies, but not really as a unique individual with a particular opinion on the matter.

Liam in particular seems frustrated with Brodie's obscure addressability. In lines 69-74, he offers two possible arguments having to do with "a good life," implicitly asking Brodie to identify which one he is talking about. Brodie resists the binary choice, saying "I don't know if it's limited to just those two" (line 75), and reiterates his ambiguous stance: "I thought that question that was raised was very interesting" (lines 75-76). Echoing the terminology of signing one's name which Liam used in his first question (line 20), Brodie then says that he does not necessarily agree that "that's a probable cause for an abortion" (line 77). I take this to mean that he does not necessarily believe that the possibility that a child will inherit a bad life should preclude someone from giving birth. As he explains this, he notes that he is "very pro-choice for the first two trimesters" (line 77) and does not think that someone needs any particular reason to abort a pregnancy within that time frame (lines 77-78). In the third trimester, however, he believes that abortion should be limited to cases related to fetal viability and the health of the mother. Concluding this turn at talk, Brodie returns once again to the name-signing metaphor, saying that while he would not necessarily approve of someone choosing not to have a child because of climate change, he thinks that people have to start considering the environment their children will inherit. It may be that Brodie's position is that, during the first two trimesters, people can choose to have an abortion for any reason they see fit, and the likelihood of their child inheriting a good life is a valid reason-one that prospective parents should take into consideration; but Brodie does not explicitly connect his pro-choice stance during the first two trimesters with his other musings, and he only indirectly states his opinion in terms of what he will not sign his name to. 


\section{Relational Becoming: Considering Classroom Dialogue in Ethico-ontological Terms}

Once again, in lines 83-84, Liam pushes for Brodie to make himself more directly addressable in relation to the ideas he is raising. This opens a series of questions in which Liam and I, speaking in the second person, characterize Brodie's opinion for him: "You're just stating..." (line 83), "You would say..." (line 86), and "You wouldn't judge..." (line 91). Perhaps tired of Brodie's repeated obscurations, we speak for him, providing him words that he can either accept or reject. He responds, repeating that, while he does not agree with every facet of the argument, he thinks people should be raising these questions (about the quality of life a child will inherit) and that such considerations could provide a legitimate reason to get an abortion. When pressed, he ultimately says, "I don't know if I could see a moral reason for" aborting a pregnancy of a viable child at the $39^{\text {th }}$ week (line 94). Although, as I read it, there remain several loose ends in this exchange, Brodie's answer seems to satisfy Liam, his most insistent questioner, and the conversation moves on.

One way to read this episode-which, in fact, reflects my original orientation to Brodie's mode of participating in our discussions-is to blame Brodie for his loquacious and circumlocutory discourse. However, from a dialogic perspective, his utterances must be viewed as a joint accomplishment and not simply as Brodie's fault. This is because, first, Brodie's previous and imagined interlocutors play some role in shaping how he tends to speak, not simply because of habits he has developed, but because, in many ways, he continues to respond to them - rather, it sometimes seems, than those he is physically present with - and, second, the other members of the group (myself included) were complicit to some degree in Brodie's utterances. In making ourselves addressable, asking questions, listening, and, most obviously, facilitating the discussion in certain ways over time, we allowed for and jointly co-authored certain responses.

Consider, for example, how all of the follow-up questions and assertions seek to render Brodie addressable in terms of his opinion while not actually offering any particular addressability themselves. Though they invite a certain response, the questioner is not made explicitly present in the asking. When Liam tries to clarify Brodie's point by outlining, as he sees it, the two possible arguments Brodie might be making (lines 69-74), Brodie's response, "I don't know if it's limited to just those two. I just, I thought that question that was raised was very interesting" (lines 75-76) might be understood as an attempt to side-step a potential trap. Unsure of what Liam thinks, which of the options he and other group members might be more sympathetic to, and how they might respond, Brodie plays it safe with an ambiguous stance.

Although, in terms of amount spoken in our discussions, Brodie was the opposite of Noemi, like her, he struggled (in dialogue with the rest of the group) to become addressable as an individual with a unique voice and perspective. Despite his many comments, the group often did not really encounter Brodie himself; instead, we encountered Brodie the ventriloquist as he gave voice to a variety of different people. This affected the quality of our relational becoming in part because it was unclear who we were responding to and how we might address Brodie. As I consider my own experience, I think, regrettably, that Brodie was presenced to me primarily as a problem - as a verbose and sometimes convoluted interlocutor who tended to monopolize the discussion. Attending myopically to this aspect of my student interlocutor limited the possibilities of our relational becoming.

\section{Episode \#3: Overlooking a Possible Address (Group 2)}

The next example comes from one of Group 2's discussions, and it features Rosa's only unsolicited comment. Rosa only attended seven out of the twelve sessions that took place between October and November 2019. She was classified as an English Language Learner and was rather reticent during the discussions but was often talkative and giggly in the time before and after, especially with Yvette, her closest friend in the group. On the day of this discussion, as we walked to our meeting place in the library, I told Rosa and Yvette that I would love to hear their thoughts about toxic masculinity during our discussion. 
Yvette responded, saying, "But you always ask questions to go deeper" (Memo 11/20/2019). I responded, saying that I was not planning to intervene much during the discussion, so she would not have to worry about that.

The portion of the discussion from which the following excerpt is taken was largely a response to a YouTube video we watched, in which a female narrator argued that the use of the term "toxic masculinity" discouraged masculine behaviors that are actually beneficial to society. Several students, Jimena and Sandy in particular, had taken issue with this argument, drawing on their lived experiences to speak back to the narrator. The group had discussed how, contrary to the argument of the video, women (including Jimena's and Jabari's mothers) are perfectly capable of raising children on their own, though they amended this stance slightly by saying that it was still important to have a father figure of some kind. Subsequently, Jimena had introduced a new idea about how the video we watched had implied that it was bad for men to be effeminate-an idea she disputed. During this time, Yvette and Rosa had been whispering and writing in Rosa's notebook in what seems to be preparation for the following comment. It is not entirely clear in the video, but it seems that Yvette wrote out "I don't need my father for be happy" for Rosa. After Jimena spoke, Rosa said:

\begin{tabular}{|l|l|l|}
\hline Rosa & I... & 1 \\
\hline David & Yeah? & 2 \\
\hline Rosa & $\begin{array}{l}\text { I feel like for me like, I don't need my father for be happy. I can be happy with } \\
\text { my mom, [throws hands up] only me and her. [throws hands up] Like that's... }\end{array}$ & 3 \\
\hline Amala & $\begin{array}{l}{[\text { Raises hand] [David: nod] So, adding on to what she [pointing to Sandy] said }} \\
\text { about how she [the female narrator] made women seem weak, she like used } \\
\text { stereotypes of women and men. Like, men should be strong, like this type of } \\
\text { thing and then, women need a strong man, but she should've like made them } \\
\text { both seem equal. 'Cause she... yeah. }\end{array}$ & 4 \\
\hline
\end{tabular}

By volunteering this comment, Rosa made herself newly addressable as a willing participant in the discussion (something I was eager to support) and by alluding to her relationship with her parents, she made herself addressable as someone who believes she does not need her father to be happy. This allusion had the potential to flesh out her physical presence, making her addressable in at least these two new ways. However, rather than responding to this newly addressable Rosa, Amala returned to an idea that had been brought up previously. Perhaps it was Rosa's accent combined with her previous reticence which, for Amala, may have raised questions about her willingness and ability to elaborate in English; perhaps it was the possibility that the story would be intensely personal and uncomfortable for the group to discuss; or perhaps it was the fact that Rosa's comment did not follow directly from the preceding comment or add much conceptually to the discussion; whatever the reason, Amala's comment does not address Rosa at all. Though Rosa theoretically remained addressable as someone with a potentially fraught history with her parents, the group never addressed her as such, and her presence in the group was largely unchanged, despite the self-revelation explicit and implicit in her comment. Rather than addressing Rosa, Amala addressed the video's narrator as someone who uses problematic gender stereotypes. As other students responded to this critique, the narrator was presenced to the group perhaps more than Rosa.

Amala's response is understandable in the context of a classroom discussion. In some ways, it fits better in the flow of the conversation than Rosa's comment because it more directly advances the 
conceptual discussion and more clearly follows Jimena's comment. Understood conceptually, Rosa's comment does not add anything new to the conversation, but from the perspective of relational becoming, it opens up the possibility of encountering Rosa and her parents as individuals with unique voices and perspectives. Because Rosa only alludes to the story, she leaves much of the work of addressability (of herself and her parents) to her classmates who do not seem to notice or respond to her newly addressable and storied self. As a result, her presence in the group remained largely unaffected.

\section{Episode \#4: Presencing and Addressing Potential Interlocutors (Group 3)}

This excerpt comes from one of Group 3's discussions about toxic masculinity, after several students shared ideas and personal stories about how men and women are treated differently in certain situations. Brandin talked about how his grandmother always asks him to take out the trash rather than his female relatives, Aliyah talked about how her mother insists that her brothers carry heavy groceries in from the car, and Carlos talked about how women sometimes got paid less than men for doing the same job. Riffing on this theme, Patience related the following story:

\begin{tabular}{|l|l|l|}
\hline Patience & Yeah. My mom used to, well she still do make the boys, him [Brandin] and & 1 \\
& my brother cut the grass. [David: Mm-hmm.] And I used to like, go out & 2 \\
& there and wanna help and stuff and she used to be like, nah, nah. And I'm & 3 \\
& just like, why can't I help like [David: Mm] just 'cause I'm a girl, don't & 4 \\
& mean nothing. I'm a girl and I do a lot of stuff. [David: Mm-hmm.] Like I'm & 5 \\
& a girl and I lift a lot of stuff and it just kinda irritating sometimes 'cause it's & 6 \\
& like, you don't see the value in what girls have. You just see that [David: & 7 \\
& Right] men are supposed to be like [David: Hm.] more like aggressive or & 8 \\
& stronger, when that's not the case. [David: Yeah.] I mean this is not a bad & 9 \\
& thing but like, I wish they would, they would see that in women too. & 10 \\
\hline David & Yeah. Yeah so what I hear you saying this, like, I said, you know, it could & 11 \\
& be a good thing to say men are brave and strong or whatever, but you bring & 12 \\
& up that, the danger in that is, if by saying that, you imply that women are & 13 \\
& not that, right? Like if men are brave and strong, what does that mean about & 14 \\
& women? And one thing that people could say is like, that means women are & 15 \\
& not so much those things. Right? & 16 \\
\hline Patience & Mm-hmm (affirmative). & 17 \\
\hline David & Yeah. So, I've, I think that's a, good point. & 18 \\
\hline
\end{tabular}

In her first turn at talk, Patience begins by telling a story about how she, as a girl, was discouraged from mowing the lawn (lines 1-3). This portion is spoken in the habitual past ("used to"). Although it is not entirely clear where the story stops, and if a younger Patience ever explicitly resisted her mother's gendered division of household labor, the verb tense shifts at the end of line 3 to the present tense. Whether or not her self-quotation (starting with "I'm just like" on lines 3-4) is meant to be part of the story or to reflect her current thinking, it represents a response to her mother. Note how the story makes Patience's mother addressable and how Patience addresses her directly, using the second person (lines 6-9) to articulate her frustration and assert herself as a capable woman. As she concludes her comment (lines 9-10), Patience broadens her response to a generic "they," suggesting that the issues she encountered with her mother are 
prevalent beyond her household-that her mother is part of a vague collective that tends to see certain characteristics in men and not in women.

Following both Patience's lead and my own schooled inclinations, my response addresses this final comment and fails to address anything other than the supposed message of Patience's story. This comment takes what "I hear [Patience] saying" (line 11) and translates it into a generalizable principle-that the danger of having a normative vision of masculinity is that it implies that women do not/should not have the characteristics ascribed to men. Although I believe there is value in this kind of reflective listening, in this case, it ignored the presence and addressability of Patience's mother. After Patience confirms that this was what she was saying, I characterize the idea as a "good point" (line 18). Indeed, it seems that her story became, in my mind, merely a vehicle for a message, and that, in the end, the message was all I heard her saying. Consequently, I do not address Patience as anything other than someone with a point to make in the discussion, as the owner of a certain idea, nor does it occur to me to address her mother.

In this episode, we seem to fail to fully address two interlocutors who became newly addressable: Patience and her mother. Patience's mother was, of course, not physically present (though she was certainly presenced in significant ways to Patience), and was represented secondhand, but she is still a person with a particular point of view who could be presenced and rendered addressable in a variety of ways to the group. To be clear, I am not suggesting that we necessarily have the same ethical obligations to narrativized individuals as to those with whom we are physically present, but I think we do have some obligations and can mutually benefit from seeking to be in dialogue to the extent possible. In this example, by giving voice to and addressing her mother, Patience was able to articulate some of her own thoughts and feelings, but her final comment closes off her mother's addressability, suggesting that her story is an example of a broader trend and, relatedly, that her mother need not be addressed as a unique individualat least, not by anyone else in the group. Perhaps this abstractive closure functions to protect her mother, or perhaps it is simply due to some schoolish sense that a comment should do more than tell stories-that it should have some generalizable message. Whatever the reason, neither Patience nor other members of the group address her mother further, and her presence in the group quickly wanes. Likewise, Patience herself is addressed simply as someone with a "good point" (line 18), not as a young woman who has felt that her gender excludes her from certain activities and makes other people, including her mother, view her as less capable than she considers herself to be. Rather than dealing with any of the emotional or relational complexities of her story, the conversation proceeds based solely on an abstraction. This seems largely due to my response, which treats her story as a vehicle for her final comment, translating it entirely into an abstract plane. This kind of response was the result of how Patience (and her mother) were presenced to me, and this presencing was shaped by our discourse, the quality of my attention and attunement to Patience's comments, and, relatedly, my sense of the discussion genre.

This episode reveals a pattern that will be evident in the following two examples, namely, a tendency to translate stories into abstractions and to relate to each other as bearers of ideas, and not as embodied, thinking-feeling, storied selves. Patience's abstraction of her mother seems to manifest an emerging form of this pattern, while my response and the following examples show it in its maturity.

\section{Episode \#5: Reducing a Story to a Moral (Group 1)}

The following example comes from Group 1's discussion of physician's assisted suicide (PAS) in which Liam, after telling a personal story, immediately translates it into an abstract principle. Remember that this group was composed of undergraduates studying at a prestigious university, something that is evident not simply in their diction, but in their fluency with abstractions. My growing sense is that this discursive move is the kind of thing that is cultivated and rewarded in school and, consequently, something that successful students like Liam are well-practiced in. While this kind of abstraction is not inherently bad, 
it comes at a cost. Notice how, in the following example, it forecloses certain forms of presencing and addressability:

\begin{tabular}{|l|l|l|}
\hline Liam & Okay, so this is pretty intense and extreme but... So, okay. My stepdad, he has this & 1 \\
& kind of... He's got this muscle disease, and that means his muscles are slowly & 2 \\
& degenerating. And, there might come a time where he just won't be able to move, & 3 \\
and will be tied to a bed, because... He just won't be able to do anything else. And & 4 \\
he's very adamant about not wanting to live anymore at that time. And since, I & 5 \\
think, in Germany, I don't think it's legal, so what he wants... He basically has this & 6 \\
plan where there's this procedure where we could bring some kind of poison to his & 7 \\
room, we would have to leave the room, so that we're not culpable, and then he & 8 \\
can just ingest it himself. So that's what he says. It's intense. And he doesn't want & 9 \\
to do it now, he's fine right now. But, what I'm saying is it's certainly possible to & 10 \\
commit suicide without a physician's assistance. So what are the arguments that & 11 \\
it's so necessary? Why would... I don't understand why you would go to the & 12 \\
trouble of moving to a different state and doing all this legal application, when & 13 \\
& you can- there are other ways to end your life. & 14 \\
\hline \multirow{5}{*}{ Joe } & I mean, I think part of that might just be... I'm trying to be super careful. Maybe \\
the way that suicide is viewed in this country, and in society... I don't know. I just & 15 \\
feel like if somebody was struggling with something, with an illness or & 16 \\
something, and I said, "Hey, why don't you just go kill yourself?", that probably & 17 \\
would not be received, I think, as well as if, kind of saying to them, "How about & 18 \\
you kind of go talk to your physician and kind of see what kind of options are & 19 \\
available?" And I just think maybe it's kind of... I don't know. The culture, or the & 20 \\
connotation of just committing suicide, kind of on your own, that kind of prevents & 21 \\
people from wanting to do that. Because, I mean, I think you're right. There's no & 22 \\
reason that these other people can't commit suicide. But I do think it's kind of just & 23 \\
that... I don't know, culture connotations kind of associated with it on its own. & 24 \\
\hline
\end{tabular}

In his comment, Liam makes his stepfather addressable, prefacing his comment with the acknowledgement that "this is pretty intense and extreme" (line 1). After telling about his stepfather, he concludes, saying, "So that's what he says. It's intense" (line 10), adding as an assurance, "And he doesn't want to do it now, he's fine right now" (lines 10-11). As I read it, these are the only moments in this exchange in which Liam's stepfather is addressed (along with Liam himself), albeit tangentially, as an embodied, thinking-feeling being; everywhere else, his story is represented and responded to merely as an illustration of a principle. After telling the story and assuring the class that his stepfather is not currently contemplating suicide, Liam says, "But, what l'm saying is it's certainly possible to commit suicide without a physician's assistance. So what are the arguments that it's so necessary?" (lines 10-12). This comment not only translates the story into a concept (i.e., that suicide does not require a physician) but explicitly invites a response on the same plane of abstraction, making his stepfather addressable merely as an example of a concept, subsumed within a broader whole, and limiting, in the process, his unique presence in the group. And indeed, Joe responds on this plane of abstractions, even conjuring up a hypothetical person "struggling with...an illness or something" (lines 18-19), rather than addressing Liam's stepfather. His comment, "I think you're right" (line 25) is revealing in this regard, implying that he understood the comment, story included, as nothing more than a defensible point in an argument and not the revelation of newly addressable Others. This simplifies the story to a moral and, in the process, limits the presence of its characters (who have simply functioned as vehicles for the moral). 
As noted, this is the kind of response Liam invites; Joe complies, and together they jointly accomplish the abstraction of Liam's stepfather. In the end, the living reality of a person facing the prospect of a bedridden life and a stepson asked to endorse and perhaps even play a complicit role in a suicide has been replaced by a hypothetical somebody and an abstract principle. Liam acknowledges the intensity of his story, but otherwise makes himself addressable simply as someone familiar with his stepfather's plans and who sees them as evidence of the idea that suicide is already accessible to anyone willing to carry it out. By telling the story, Liam makes himself addressable as a stepson of someone with suicidal contingency plans related to his muscular degeneration, but by translating the story into a specific principle and inviting abstract responses, he is presenced simply as a knower-as someone with a particular stance in the ongoing discussion. And, predictably, this is how Joe addresses him-and there is no further mention of Liam's stepfather.

\section{Example 6: Approaching (and Retreating from) Different Kinds of Presence and Addressability (Group 2)}

My comments in this final example manifest a similar pattern, though I think they also show a nascent sense of a potentially more ethically optimal mode of facilitating discussions. This episode took place during Group 2's third and final discussion about abortion, in which Jabari shares with the group that his mother had aborted a pregnancy "a long time ago." This was particularly notable to me because, up to this point, Jabari had generally argued for positions that would be considered "pro-life." In our very first discussion, for example, after Sandy suggested that a family without the means to provide for a child would be justified in getting an abortion, Jabari said, "If they're like poor and stuff, and don't have enough money to take care of the baby, then can't they just like put it up for adoption instead of killing it?" He seemed to view abortion as a form of homicide and consequently struggled to justify it as an alternative to adoption, so I wondered if learning that his mother had had an abortion would be disturbing and disorienting.

On the day of the final discussion, I had asked the students to write in their journal about the abortion policies they would institute if they had the chance. This admittedly simplistic prompt was designed to elicit and concretize students' opinions in order to help them take a stand and engage with the implications of each other's ideas. Jabari volunteered to begin the discussion by paraphrasing his journal entry, saying that he thought abortion was justifiable in some situations (e.g., in the case of rape), adding, "but like if you're getting pregnant like with your husband and then you guys just like don't want the baby at all, then that's when I think you should just have the baby and put it up for adoption." Noting some exceptions, he still positions himself as generally opposed to abortion, focusing his attention on a hypothetical situation in which adoption would be preferable to abortion. Following Jabari, Jimena explained that she would permit abortion "if like you don't have the funds," comparing her ideal abortion policy with the way the government provides health insurance for people below a certain income level. Jabari seemed to appreciate this idea, remarking affirmatively, "Yeah, it just depends on the situation." When Jimena finished explaining her idea, the following exchange took place:

\begin{tabular}{|l|l|l|}
\hline Jabari & Another thing is that- Well, this has really nothing to do with like, [gesturing & 1 \\
& to what he had written in his notebook] this whole thing, but I asked my mom & 2 \\
& about it and it turns out she actually had an abortion a long time ago and she & 3 \\
& was actually supposed to have twins, another set of twins, and I guess she & 4 \\
& didn't decide to have them because she didn't have enough funds at the time, & 5 \\
& and that was like a while back. So we would- we would have like, six people & 6 \\
& in our house. [David: Hmm.] Which would've been a lot. & 7 \\
\hline David & Interesting. Well, so what do you think about that? & 8 \\
\hline
\end{tabular}




\begin{tabular}{|l|l|l|}
\hline Jabari & $\begin{array}{l}\text { Um, I think it's understandable. She told me why she couldn't really have } \\
\text { them, and I wasn't like angry at her for that or anything, so... Like, yeah I } \\
\text { guess it's really just situational, really. Yeah, that's all I have. }\end{array}$ & 9 \\
\hline David & $\begin{array}{l}\text { Interesting. How does- so I'm- if you don't mind sharing, how does your- does } \\
\text { your mom feel like that was the right thing to do? Does she- }\end{array}$ & 11 \\
\hline Jabari & $\begin{array}{l}\text { She said she kinda like... She says the- she kinda like... Well, she said it } \\
\text { would've been hard to raise like all six of us, because she was a single mom } \\
\text { for like most of her life, and she had like her first baby in her senior year, so } \\
\text { she kinda just like- She never really had like, a personal life. She's always had } \\
\text { to like, take care of, us the entire time, and I guess she just didn't wanna, have } \\
\text { that many people to deal with, 'cause she would've still had like way more } \\
\text { kids, and by the time we were all grown up, she probably would've passed } \\
\text { away or would've been like, super old by now. She hasn't really had any time } \\
\text { to herself, really, because she's been taking care of all of us, so. }\end{array}$ & 13 \\
\hline & $\begin{array}{l}\text { Interesting...So far I'm hearing people are saying there are situations when } \\
\text { abortion is okay. We seem to agree that rape is one of those. Do we all agree } \\
\text { that uh poverty is another reason for [Students "Mm-hmm" affirmatively]... } \\
\text { Does anyone disagree? Would anyone say that's not a good enough reason?...I } \\
\text { guess I'm thinking about Ivan, Yvette, and Jared. You've tended to be more on } \\
\text { the pro-life side. Would you say if someone's poor, they should be able to get } \\
\text { an abortion? }\end{array}$ & 18 \\
\hline
\end{tabular}

In his first turn at talk, Jabari begins by separating the story he is about to tell from the journal entry and, by extension, his earlier comment, saying, "this has really nothing to do with like...this whole thing" (lines 1-2). This seems both to create space for him to tell a story that may not align with the stance he has generally taken in our discussions, and to set the story apart from the ongoing discussion. He proceeds to tell the story, which is both autobiographical ("I asked my mom about it," lines 2-3) and biographical ("she actually had an abortion a long time ago and she was actually supposed to have twins, another set of twins," lines 3-5), a tension that lingers throughout this episode. With the basic narrative told, he says, "I guess she didn't decide to have them because she didn't have enough funds at the time" (lines 5-6). I suspect that this is his own commentary more than the continued retelling of his mother's story both because he begins with "I guess" and because he uses the term "funds," which Jimena introduced. This latter point is significant because, in the context of the discussion, the word invokes a situation in which abortion would be considered permissible. As he makes his mother addressable to the group, he introduces her as someone who meets the criteria Jimena introduced for justifiably aborting a pregnancy. The comment concludes on a similarly sympathetic note, as Jabari imagines what it would have been like to have two additional people in the house (lines 6-8).

In response, I simply say, "Interesting" (line 9) and ask what he thinks about that. This is a pedagogical move oriented toward responsibility, a response to the sympathetic but noncommittal quality of his storytelling. I seem to want him to reconnect the story and "this whole thing" (line 2)—our discussion about ideal abortion policies. He responds first somewhat vaguely in terms of his emotional reaction, saying that his mother's choice was "understandable" and he says, "I wasn't like angry at her" (lines 10-11). Describing his reaction in negative terms implies an audience that might have expected an angry response, 
suggesting again that Jabari is aware of the possible discrepancy between his mother's choice and his own previously stated opinions. Perhaps sensing this and, relatedly, that I want him to take some kind of stand, Jabari restates the idea he formulated in response to Jimena's proposal with an ambiguous stance, saying, "I guess it's really just situational" (line 12). In this moment, Jabari's ambiguous stance seems to provide him some space to process and withhold judgement on his mother's story which, as I learned in a subsequent interview, she may have told him only the night before this conversation.

Given this context, an ambiguous stance of this kind is certainly understandable and seems indicative of Jabari's evolving understanding. It also indicates something about what he thought I intended with my question. Although the question "what do you think about that?" could yield a wide variety of responses, he seems to interpret it as a request to take a stand that can be articulated in terms of a general principle. Given my orientation toward abstractions evident in my response to Patience's story and at the conclusion of this episode, Jabari's interpretation seems reasonable. His comment "Yeah, that's all I have" (line 12) can be read as a bid to be excused not simply from further comment, but from this kind of comment, as if to say that he does not necessarily want to subject his mother's story to this kind of schoolish scrutiny.

Sensing that Jabari may not be comfortable opining on his mother's choice but also wanting to continue discussing the story he shared, I change tack and ask him to speak on his mother's behalf. The question I initially begin to articulate asks how she feels about her choice, but I ultimately narrow the question to whether she thinks it was the right thing to do (lines 12-13). This narrowed question resonates with my broader tendency toward abstract concepts and limits the responses available to Jabari-in fact, it affords a yes/no answer-but it also represents a moment of seeking to address an interlocutor: Jabari's mom, who has been made newly addressable through storytelling; it invites her voice into the discussion. Jabari struggles at first to speak for her (line 15), but eventually finds a rhythm, imagining what it would have been like to be a single mother of six kids. Perhaps the struggle is to respond to my narrowed question (something he never actually does) or to share something so personal and still somewhat unprocessed, but it also seems to reflect Jabari's simultaneous search for both his mother's voice and his own. As he remembers what his mother told him, imagines her choice and retells her story, we see him dialogically portraying her not only for the group, but for himself. A twin himself, Jabari seems to identify with his imaginary unaborted siblings, using the first-person plural ("all six of us," line 16) and entering into the timespace of this alternative reality ("she probably would've passed away or would've been like, super old by now," lines 22-23). Indeed, by the end, this imagined world and the present are blurred, as he speaks in the perfect ("hasn't really had any time to herself," line 23) and perfect progressive ("been taking care of all of us," line 24) tenses, suggesting that this is not purely hypothetical. In other words, Jabari is not simply imagining how his mother would justify her choice; he has begun to "translate" the story from her point of view into his. He is not merely giving voice to her but is retelling and reworking her story in his own voice and from his own perspective. I think this is also evident in the tonal shift that begins at lines 19-20, when Jabari begins to speak in a less formal, more hyperbolic, and less fragmented style.

In doing this, Jabari renders his mother addressable as a single mother of four whose first child was conceived in her senior year (of high school, I presume); a woman who at one point in time was struggling to take care of both herself and her children, who decided that, rather than bearing another pair of twins, it would be best to abort her pregnancy. Although I have never met Jabari's mom, I began to imagine her, a woman making complicated choices in a world that surely has not always been hospitable to her. There are obviously dangers of stereotyping and other forms of assumption-making in this kind of characterization, but it represents how Jabari's story presenced a potential interlocutor to me-someone I might address, whose voice I might, to some degree, hear and respond to. While Jimena's proposal was an interesting thought experiment, Jabari's story introduced us to a person who was actually in a position to decide between pregnancy and abortion. 


\section{Relational Becoming: Considering Classroom Dialogue in Ethico-ontological Terms}

Of course, by telling the story and responding to my questions, Jabari did not simply make his mother addressable, but also made himself addressable in new ways to the group, particularly with regards to his upbringing, family situation, and evolving perspective on abortion. In a sense, the constitution of the group had changed, as Jabari became Jabari-with-a-mother-this particular mother who had also, in a way, joined the group. Although she was certainly present for Jabari in significant ways throughout this episode, her presence in the group was limited by the ways we responded to her story. All of this is ethicoontologically consequential because it makes group members capable of new and different responses to differently addressable and presence-able interlocutors. By telling the story, Jabari invited us all, himself included, to grapple with his mother's complicated choice, to hear her voice (as well as his own), and to respond. It also invited us to understand abortion not merely in terms of abstract principles, but as a thing in the world which is made meaningful in particular ways to diverse individuals in unique situations. In other words, it afforded us the opportunity to encounter a new interlocutor (or a familiar interlocutor in a new way), a person for whom abortion has some particular meaning, and to respond to them from our unique place in Being.

In that light, the final move I make as a facilitator in lines 25-31 strikes me as a failure to tap much of the ethico-ontological potential of Jabari's story, to address the interlocutors that had become newly or differently addressable. Perhaps because Jabari had already made a bid to be excused from further comment (line 12), perhaps due to the sensitivity of the topic, perhaps simply in an effort to involve other students in the discussion, particularly those who tended to be more pro-life, I shift the focus away from the story, summarizing the group's preliminary consensus, and asking if anyone disagrees with the idea that being poor is a sufficient reason to abort a pregnancy. While there may be nothing inherently wrong with this move, in this instance, it does two problematic things: It translates Jabari's story into an abstraction, something he never does, and removes all reference to his mother. The former imposes my reductive interpretation of the story and the latter depersonalizes the idea. Although I implicitly ask students to respond to Jabari's story, I seriously constrain the kinds of responses they might give; rather than inviting them to respond to Jabari or to his mom, I ask them to respond to my depersonalized abstraction of their story, limiting the possibilities of relational becoming.

\section{Discussion}

What can we learn from these episodes about addressability, presencing, and ethically optimal dialogue? Looking across these examples, one pattern that stands out is our schooled tendency to address each other on the ideational plane-with regards to our ideas, opinions, reasons, and beliefs-even when other forms of address are available. Indeed, as I expect is the case in many classrooms, there was a clear tendency to relate to each other in terms of abstractions. This is evident both in how group members made themselves and narrativized Others addressable to the group and in how they responded to each other. In a variety of ways, we failed to relate to each other as unique persons with a particular perspective-as uniquely embodied, storied, relationally enmeshed, thinking-feeling persons-in-dialogue. Instead, we addressed each other and narrativized Others as idea- and opinion-holders, and instances of principles. This both stemmed from and affected the ways in which we were presenced to each other.

For those who are familiar with Bakhtin's (1984) insistence that speech is always addressed to interlocutors and, consequently, contains "a thousand reservations, concessions, loopholes and the like" and "cringes in the presence or the anticipation of someone else's word, reply, objection" (p. 198) may not find my analysis of addressability and presencing in these discussions particularly surprising. It is to be expected that interlocutors would, anticipating possible responses, conceal or protect themselves discursively. I agree. What my analysis adds to this insight is, first, documentation of particular kinds of "loopholes" that seem widespread in classroom discussions and, second, the concern that the widespread 
use of such loopholes may limit the relational becoming of the interlocutors. This concern is not so much that individuals are failing to speak responsibly but that the genre of classroom discussions does not afford certain kinds of responsible speaking.

There is nothing inherently wrong with addressing someone on the ideational plane, but if that is the predominant way that they are addressed, only certain kinds of relational becoming are possible. Assuming that the patterns I have documented here are similar to those in other settings, it is likely that interlocutors' relational becoming in these contexts is driven primarily by their articulation of abstract ideas, opinions, beliefs, and reasons, rather than any number of other possibilities. This limits the kinds of becoming that are likely to occur and excludes some interlocutors from certain kinds of presence, participation, and validation.

As I consider the discussions I facilitated in retrospect, I am not satisfied. In my judgement, my student-interlocutors and I would make ourselves addressable in ways that now seem somewhat irresponsible and address each other in ways that do not seem particularly responsive, rendering each other capable of only certain kinds of responses, including silence. Our relational becoming was significantly limited. While there were moments of generative vulnerability and vitality, by and large, we tended to approach each other guardedly, as if our interlocutors were somewhat dangerous or antagonistic. To the extent that this is characteristic of classroom discussions more broadly, it suggests that the genre constrains some of the ethical dimensions of dialogue and, therefore, may not be ethically optimal.

Although these tendencies are partly due to the conventions and systems of schooling which are resistant to change, perhaps, newly attuned to our discussions in light of the ethical dimensions of dialogue and addressability/presencing, there are small steps researchers and educators might take to relate to students differently and tap some of the latent potential in many of their comments.

\section{Reimagining Our Interactions}

In considering how, in the course of a discussion, my responses might foster different kinds of relational becoming, I return to two interactions analyzed previously and draw on the ethical dimensions of dialogue to imagine how I might have responded to my student-interlocutors more responsibly, responsively, and capacitatingly. The first example is the simple exchange between Noemi and me, previously discussed as Episode \#1:

\begin{tabular}{|l|l|l|}
\hline David & Noemi, do you want to share? & 1 \\
\hline Noemi & $\begin{array}{l}\text { It's a long story but like, I don't know like the full story because like usually I never like, } \\
\text { listen to my, [David: Mm-hmm] my mom say it, [David: Mm-hmm] } \\
\text { but like when she tells my other siblings. }\end{array}$ & 2 \\
\hline David & Do you want to share anything you do know or? You don't have to. & 3 \\
\hline Noemi & I, I don't know the full story, so. & 4 \\
\hline David & Okay. & 6 \\
\hline
\end{tabular}

How might I have responded differently, in ways that might have fostered different kinds of relational becoming? One possibility, informed by responsibility, is to make myself more explicitly present in how I invite Noemi to share. As it is, my repeated question "do you want to share?" places the onus of ethical accountability on her. An alternative would be something like, "I would like to hear your story too, Noemi." Phrasing the invitation in this way renders me addressable as someone with an interest in her story, while the original question only renders me addressable abstractly as the one asking the question. The ethicoontological potential I see in making myself more explicitly addressable as myself is that it might make it 
more likely that my student interlocutors would respond to me-myself rather than to me in my role as the teacher/facilitator-I might become presenced to them differently. While there is no guarantee, it is possible that this shift in my presence/addressability would yield a different response from Noemi. Of course, there are dangers in this alternative, most notably in asserting the authority of a teacher to compel students to speak, and this should be taken seriously. However, dialogue is never entirely safe, so the fact that some versions of speaking responsibly entail some risk does not necessarily mean that it would be better to avoid that particular risk entirely. As always, what is at stake in this interaction is who we understand ourselves and our interlocutors to be, and what we understand ourselves to be doing in dialogue with each other. Shifting the ways in which we make ourselves addressable may alter, however slightly, the possibilities of relational becoming.

A second possibility, informed by responsiveness, is to pay more careful attention to and to be moved by the ways Noemi makes herself addressable. In the transcript, after Noemi sidesteps my initial question, I respond by asking an only slightly adjusted question. Acknowledging that she does not know the full story, I ask, "Do you want to share anything you do know?" Although this question accommodates Noemi's concern about the partiality of her knowledge, it does not change direction at all but simply reiterates the invitation to share her story. Perhaps by being moved more radically, my response would yield different possibilities of relational becoming. For example, in response to her comment that she does not listen when her mom tells the story to her siblings, I could have said, "So you never listen to your mom tell the story? That's interesting. Why is that?" This is not to say that Noemi was deliberately offering to speak about her family; as noted, I think her comment is best understood as a bid to be excused. Assuming that to be the case, however, the comment was, crucially, a bid to be excused from the discussion-from the genre of activity as she understood it. Allowing myself to be radically moved by how she makes herself addressable is not a way to trick her into participating in the activity as I understand it; it represents, instead, a willingness to suspend my understanding of the nature of the activity as it unfolds and to allow my interlocutors to be presenced differently in the group.

The final ethical dimension of dialogue, capacitation, invites us to consider how we might render our interlocutors capable of different and potentially better responses. Recognizing that the prospect of sharing her family's story on the spot might be daunting to Noemi, I could find ways to facilitate her response. One way to do this would be to ask, "Noemi, is your family's story similar to the ones the other students shared?" A question like this might provide a kind of steppingstone to help Noemi begin telling her story. There are, of course, other, more extensive ways to do something similar. I could, for example, respond by saying, "Would you like to take some time to talk to your mom and prepare to share your story in our next meeting?" A response like this would alter the temporal/spatial (in Bakhtin's terms, "chronotopic") scale of the activity from one typical of discussions (i.e., taking place in a single sitting over tens of minutes) to one that spans home and school and stretches across multiple days, perhaps providing Noemi alternative ways to respond and become addressable and presenced in the group.

The next example I will consider is the exchange between Patience and me previously discussed as Episode \#4:

\begin{tabular}{|l|l|l|}
\hline Patience & Yeah. My mom used to, well she still do make the boys, him [Brandin] and & 1 \\
& my brother cut the grass. [David: Mm-hmm.] And I used to like, go out \\
& there and wanna help and stuff and she used to be like, nah, nah. And I'm & 2 \\
& just like, why can't I help like [David: Mm] just 'cause I'm a girl, don't & 3 \\
& mean nothing. I'm a girl and I do a lot of stuff. [David: Mm-hmm.] Like I'm & 4 \\
& a girl and I lift a lot of stuff and it just kinda irritating sometimes 'cause it's & 5 \\
\hline
\end{tabular}




\begin{tabular}{|l|l|l|}
\hline & $\begin{array}{l}\text { like, you don't see the value in what girls have. You just see that [David: } \\
\text { Right] men are supposed to be like [David: Hm.] more like aggressive or } \\
\text { stronger, when that's not the case. [David: Yeah.] I mean this is not a bad } \\
\text { thing but like, I wish they would, they would see that in women too. }\end{array}$ & 7 \\
\hline David & $\begin{array}{l}\text { Yeah. Yeah so what I hear you saying this, like, I said, you know, it could } \\
\text { be a good thing to say men are brave and strong or whatever, but you bring } \\
\text { up that, the danger in that is, if by saying that, you imply that women are } \\
\text { not that, right? Like if men are brave and strong, what does that mean about } \\
\text { women? And one thing that people could say is like, that means women are } \\
\text { not so much those things. Right? }\end{array}$ & 10 \\
\hline Patience & Mm-hmm (affirmative). & 13 \\
\hline David & Yeah. So, I've, I think that's a, good point. & 16 \\
\hline
\end{tabular}

In my response to Patience, I make myself addressable as having said that it could be good to associate certain characteristics with men, and as considering her response (or at least my ventriloquation of her) which problematizes that idea to be valid. Once again, I render myself addressable as merely the bearer of certain ideas and opinions. If I were to try to speak more explicitly as an embodied, storied, and relationally enmeshed person, I might explain something of where my idea comes from and why it is meaningful to me personally. I might, for example, explain that I discipline my son when he is physically aggressive toward my daughter more than I discipline her when she is physically aggressive toward him partly because he is male and will, in all likelihood, end up physically bigger and stronger than her and other women in his life. I want to make sure that from a young age he understands that it is inappropriate for boys to hit girls. This parenting approach is based on the understanding that boys and girls are different and that those differences may justify different treatment in certain situations. By making myself addressable as a person for whom these ideas are meaningful in my relationality, I might become presenced more holistically and not merely as the bearer of certain opinions and ideas. This imagined response, I realize, would also follow suit with most of Patience's own turn at talk, rather than shifting the discussion away from storytelling and back toward abstractions, which is what I did in the original exchange.

As always, my response to Patience stems from how I attend to her and, specifically, how I recognize the ways in which she is rendered addressable. Although in the moment, I attended mostly to the conceptual substance of her comment, in retrospect, I realize that her comment renders her addressable in several other ways: as someone who is frustrated by her mother's gendered division of labor, as a capable and physically strong girl, and as someone who wishes that "they" would see traditionally masculine qualities in women too. In other words, as I have studied the transcript of our discussion, Patience has become presenced to me differently than she did in the moment. If I had been more attuned to other ways of addressing Patience, instead of reverting immediately to abstractions, I might have said, "You seem especially irritated with the idea some people have that boys are stronger than girls. I'd be interested to hear more about that." Or perhaps, noting that she seems drawn to address her mother, and sensing that this may be particularly significant for Patience, I could have responding by saying, "You said, sort of speaking to your mom, 'You don't see the value in what girls have.' Can you say more about that and about what your mom might be missing?" In both of these cases, my imagined responses would address Patience on dimensions other than the abstract point I understood her to be making, allowing both her and her mom 
to be presenced differently in the group. Though there are no guarantees, this may have engendered different and perhaps better forms of relational becoming among the group.

Recognizing that Patience had rendered her mother addressable, I could also have tried to capacitate this narrativized Other of fuller presence and voice in the discussion. For example, I could have invited Patience to sympathize with and ventriloquate her mother by asking, "Why do you think your mom has the boys cut the grass and stuff like that? What would she say if she were here?" In this way, perhaps, we would not only encounter Patience's mother more fully, but we would relate to Patience more fully in her relationality.

\section{Conclusion}

If we want to cultivate different kinds of relational becoming in classroom discussions, we must be willing to reimagine what might happen in a discussion. One way to do this is to consider alternative ways we might respond to our student-interlocutors and help them respond to each other more responsibly, responsively, and capacitatingly - to explore the kinds of relational becoming that such practices afford. Each interaction that pushes the envelope with regards to the discussion genre influences, however slightly, how students will understand what it means to participate in a discussion, at least as it relates to that particular class. And, little by little, different kinds of interactions will yield different kinds of relational becoming, as interlocutors become presenced and are rendered addressable to each other in different ways.

As I have tried to understand and respond to Bakhtin's ethico-ontological vision of dialogue, I have come to appreciate more fully the fact that we exist and live "in response"-to our interlocutors past and present and to our various senses of the "kind(s) of thing" we are doing together. This includes not simply the ideational material of these interactions, but all their embodied, relational, and storied baggage. We are inextricably entangled in these relationships, always already responding to something or someone beyond ourselves. To take this seriously requires us to rethink assumptions prevalent in schooling, including the mind/body dualism that allows us to respond to each other in a discussion as if what ultimately matters is that which can be abstracted from our stories, experiences, and relationships.

Furthermore, if we assume from the start that our student-interlocutors exist "in response," we must acknowledge that we are implicated in their relational becoming and have an ethical obligation to respond to them in ways that are likely to be generative and enriching. This is no easy task. It is challenging enough in a one-on-one interaction to discern which ethical dimension of dialogue should be prioritized and how it should be manifest in a given moment. Multiply that complexity by the number of students in a classroom and we arrive at an impossibly complex situation in which there are sometimes contradictory obligations and any number of possible responses that could be beneficial but might be harmful to certain students and/or to the group as a whole. There are no clear answers and no guarantees, and yet we must respond with the knowledge that each response is an act of partially co-authoring the world and our places in it, with implications for who students will understand themselves to be and who they will become relative to us, the disciplines we represent, their classmates, and their future.

As we seek to foster generative and enriching forms of relational becoming, the ethical dimensions of dialogue and the notion of addressability can help us sense ways in which we might respond differently, perhaps better, to our student-interlocutors. Although I have no final answers, I can offer, in conclusion, some questions that may be useful as readers consider the relational becoming among their own interlocutors and seek, in their own interactions, to foster more ethically optimal dialogue: 


\begin{tabular}{|l|l|}
\hline Responsibility & $\begin{array}{l}\text { How do I make myself addressable? To what extent am I speaking as myself, from } \\
\text { my own unique perspective, and not merely as the bearer of certain } \\
\text { ideas/opinions? How am I being presenced to my interlocutors? }\end{array}$ \\
\hline Responsiveness & $\begin{array}{l}\text { How do my interlocutors make themselves (and others) addressable? How might } \\
\text { I be moved in response to them? How are they being presenced to me? How else } \\
\text { might they be presenced to me? }\end{array}$ \\
\hline Capacitation & $\begin{array}{l}\text { How can I help my interlocutors speak as themselves, from their unique } \\
\text { perspectives, and not merely as the bearers of certain ideas/opinions? } \\
\text { How can I help my interlocutors be more responsive to each other? How are they } \\
\text { being presenced to each other? How else might they be presenced to each } \\
\text { other? }\end{array}$ \\
\hline
\end{tabular}

\section{References}

Bakhtin, M. M. (1984). Problems of Dostoevsky's Poetics (C. Emerson, Ed. \& Trans.). University of Minnesota Press.

Bakhtin, M. M. (1986). Speech Genres and Other Late Essays (C. Emerson \& M. Holquist, Eds.; V. W. McGee, Trans.). Austin: University of Texas Press.

Bakhtin, M. M. (1990). Art and Answerability: Early Philosophical Essays by M. M. Bakhtin (M. Holquist \& V. Lipunov, Eds.; V. Liapunov \& K. Brostrom, Trans.). University of Texas Press.

Bakhtin, M. M. (1993). Toward a Philosophy of the Act (V. Liapunov \& M. Holquist, Eds.; V. Liapunov, Trans.). University of Texas Press.

Clayman, S. E. (1992). Footing in the achievement of neutrality: The case of news interview discourse. In P. Drew \& J. Heritage (Eds.), Talk at work: Interaction in institutional settings (pp. 163-198). Cambridge University Press.

Emerson, C. (2000). The Next Hundred Years of Mikhail Bakhtin (The View from the Classroom). Rhetoric Review, 19(1/2), 12-27.

Goffman, E. (1974). Frame Analysis: An Essay on the Organization of Experience. Harvard University Press.

King, M. L. (1963). Letter from Birmingham Jail. Retrieved from https://www.csuchico.edu/iege/ assets/documents/susi-letter-from-birmingham-jail.pdf

Matusov, E., \& Marjanovic-Shane, A. (2018). Beyond equality and inequality in education: Bakhtinian dialogic ethics approach of human uniqueness to educational justice. Dialogic Pedagogy: An International Online Journal, 6(2009), 1-38.

Matusov, E., Marjanovic-Shane, A., Kullenberg, T., \& Curtis, K. (2019). Dialogic analysis vs. discourse analysis of dialogic pedagogy: Social science research in the era of positivism and post-truth. Dialogic Pedagogy: An International Online Journal, 7, 20-62.

Matusov, E., Smith, M., Soslau, E., Marjanovic-Shane, A., \& Von Duyke, K. (2016). Dialogic education for and from authorial agency. Dialogic Pedagogy: An International Online Journal, 4(2016), 162197.

Morson, G. S., \& Emerson, C. (1990). Mikhail Bakhtin: Creation of a Prosaics. Stanford, CA: Stanfor University Press. 


\section{Relational Becoming: Considering Classroom Dialogue in Ethico-ontological Terms}

Sabey, D. (2021). The Meaning and Practice of Dialogue: An Ethico-Onto-Epistemological Re-Reading and Exploration of Bakhtinian Dialogue. http://hdl.handle.net/1803/16608

Warnick, B., Yacek, D., \& Robinson, S. (2018). Learning to Be Moved: The Modes of Democratic Responsiveness. Philosophical Inquiry in Education, 25(1), 31-46.

Wortham, S. (2008). The objectification of identity across events. Linguistics and Education, 19(3), 294311. https://doi.org/10.1016/j.linged.2008.05.010

\section{(c) EY}

New articles in this journal are licensed under a Creative Commons Attribution 4.0 United States License.

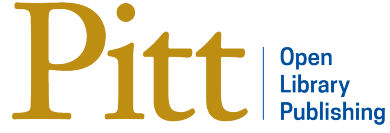

This journal is published by Pitt Open Library Publishing. 